\title{
Special Issue on Power, Politics, and Development in Afghanistan
}

Introduction

Politics and development are closely intertwined in Afghanistan. For understandable reasons, most commentary on Afghanistan has tended to focus on the ongoing insurgency; the myriad power struggles underpinning the international state-building enterprise are much less often the focus of academic study. When development policies do come under the spotlight, the approach is often highly technocratic, insufficiently taking into account the political forces that determine how programs are conceived, perceived, and received by various actors at every level, and how these factors determine what impact they ultimately have. Within a lively "aid marketplace," government ministries, UN agencies, NGOs, and private companies jostle for funding, control, prestige, and influence. Donors and the central government are engaged in ongoing negotiations regarding the conditionality and alignment of aid, where issues of trust, capacity, and vested interests play pivotal roles. The balance of power between the central government and its peripheries continues to be hotly debated. Debates about how to define, prioritize, and address critical needs, as well as how to measure the success or failure of development initiatives, are all strongly contested and influenced by organizational interests. None of these issues can be fully understood

Nematullah Bizhan is a Senior Research Associate with the Global Economic Governance Program, Oxford University, and a Visiting Fellow at the Development Policy Center, Australian National University. Matthew Willner-Reid is an independent consultant and researcher. Jasmine Bhatia is a Postdoctoral Research Fellow at the School of Oriental and African Studies, University of London. Emails: <nematb@gmail.com>, <matthew_willner_reid@hotmail.com>, <jbio6@soas.ac.uk>.

Asian Survey, Vol. 58, Number 6, pp. 967-972. ISSN ooo4-4687, electronic ISSN 1533-838X. ( 2018 by The Regents of the University of California. All rights reserved. Please direct all requests for permission to photocopy or reproduce article content through the University of California Press's Reprints and Permissions web page, http://www.ucpress.edu/journals.php?p=reprints. DOI: https://doi.org/Io.I525/ AS.20I8.58.6.967. 
from a solely technical perspective that downplays or obscures the central importance of politics.

In this special issue the authors seek to bridge the divide between the technocratic and the political. Combining considerations of power, politics, and development, this issue aims to examine struggles between various state and non-state development-oriented actors, the processes through which such conflicts are resolved, and the resulting impact on development policy and outcomes in Afghanistan. The special issue was originally conceived during a panel on power, politics, and development in Afghanistan, which took place at an International Studies Association conference in September 2016 at Oxford University.

Afghanistan offers an interesting case study in which to examine multiple intersections of politics and development from interdisciplinary perspectives. Over a decade and a half of large-scale donor investments has brought improvements in many sectors, yet it has also created tensions regarding how such funding is spent and by whom it is controlled. This issue brings together both scholars and practitioners with relevant experience in Afghanistan to explore various questions related to the political dimension of the development process there.

This issue includes eight papers, seven of which focus on Afghanistan exclusively. The eighth focuses on tribal conflict and reform in the Federally Administered Tribal Areas (FATA) of Pakistan, a region with arguably more of a direct impact on security in Afghanistan than any other. The authors explore the politics of state-building and international engagement; neopatrimonialism and the politics of aid; village-level politics and development; the challenges of late development; network politics and economic life; community-driven development; state-society relationships; and competition in the aid marketplace.

Three of our authors, Nematullah Bizhan, William Maley, and Matthew Willner-Reid, direct their analysis toward the national level and attempt to unpack the macro-level political dynamics created by various actors jostling to exert control over the national aid agenda, and the impact this competition has had on state-building. The authors agree that a competitive political arena, in which negotiated outcomes accommodating diffuse interests are the norm, has not always produced optimum outcomes for Afghanistan. Each author critiques different aspects of the national and international structures that have played a role in determining Afghanistan's national policies. 
Nematullah Bizhan examines post-20oI state-building in Afghanistan and explores how interactions among aid, politics, and capacity shaped the characteristics of the state. He argues that the types of aid that Afghanistan received after 200 and the nature of domestic politics had major implications for statebuilding and state transformation, producing paradoxical institutional and political outcomes in the long term. Institutional legacies, such as low state capacity and strong patronage networks, imposed significant constraints on the development of an effective and well-functioning state. These challenges were compounded by decisions by the donor community, particularly the lack of balance between short- and long-term objectives, along with the flow of more than four-fifths of the total aid being outside the government's budget and procurement system, which has induced institutional fragmentation.

William Maley brings greater attention to the Afghan government's problematic role in managing aid resources and developing policies. Maley examines the legacies of decisions made at the 200 i Bonn Conference and elsewhere in shaping long-term institutional dynamics in Afghanistan. Despite the establishment of sophisticated formal institutions with considerable checks and balances, the fractionalization of political power on the ground and the behavior of senior officials in the Karzai government led to the emergence of complex neopatrimonial networks that ultimately undermined state power. He argues that a large proportion of aid flowing into the country was co-opted by these networks and misdirected away from public goods for private gain, a problem made worse by poor coordination and uneven management practices by donor agencies.

Meanwhile, Matthew Willner-Reid takes a closer look at the incentives facing the wider ensemble of aid actors, including donors, UN agencies, government ministries, and NGOs (and the individuals employed within them), all competitors in the "aid marketplace" in Afghanistan. He proposes a novel interdisciplinary theoretical framework for understanding the motivations of these actors in the aid sector as being driven by "mercenary" (rational), "missionary" (altruistic), and "misfit" (bureaucratic) agendas. Within the relatively horizontal governance structures of the aid world, this competition has resulted in remarkably similar dynamics of fragmentation and a focus on narrow individual objectives over wider shared ones among donors, UN agencies, government ministries, and NGOs.

While all of these actors are engaged in a constant process of national-level negotiation over the direction of development policies, how these policies are 
actually implemented is a very different question. Ultimately, the process of transforming policies into concrete outcomes depends on subnational and community-level politics. As the experience of Afghanistan has repeatedly shown, when national policies inevitably come into contact with existing governance structures and power relations at the local level, the resulting impacts may be quite different from those intended by distant planners. These dynamics are the focus of the remaining papers in this special issue.

Jasmine Bhatia, Ross McIntosh, and Naseem Jareer examine the implementation of the National Solidarity Programme (NSP), the Afghan government's flagship rural development program, through village-level research in the province of Wardak. They find that the NSP was effective as a mechanism for distributing aid resources, but see little evidence that it led to long-lasting changes in levels of trust in formal institutions of government. And in the most insecure areas, many community development councils set up by the NSP have ceased to function or have been co-opted by insurgent forces, providing further evidence of the shallowness of the program's institutionally focused objectives in areas beset by insurgency.

Adam Pain continues the focus on the NSP, this time in two provinces, Nangarhar and Badakhshan. His research similarly draws on original primary research carried out at the village level. He finds that although communities in these provinces have embraced some aspects of the NSP, the program has not succeeded in radically transforming existing power relations at the village level. Instead, pre-existing practices and relationships have proved to be remarkably durable.

Ashley Jackson and Giulia Minoia provide further evidence for this finding. The authors delve into the political and economic relationships at subnational and local levels, proposing a theory of networks of access to explain why informal power structures are often far more important than formal institutions and policies. They argue that non-cooperation-or refusal to participate in patronage and nepotistic practices through existing networks - has serious repercussions. And they show that the same "rules of the game" apply even in policymaking spheres. As a result, network-dominated politics penetrates even the best-intentioned government programs and policies: certain networks are privileged over others, and winners and losers are continually determined in part through donor priorities.

Adam Pain and Danielle Huot provide an analysis of what they see as the failure of policy models of market-driven agriculture in Afghanistan to 
produce the gains that were expected by early planners. They argue that though agriculture has been seen as the engine of growth for Afghanistan, it has failed to deliver. Evidence from a long-term livelihood study points to a rural economy that is driven more by social than by market relations. These are underpinned by major land inequality and a distributional economy concerned with survival given the absence of rural employment. This article neatly ties together the central strands of our special issue, addressing the tensions between national and village-level politics regarding the creation and implementation of development policies. The authors end with a warning, highlighting the high human and political costs that continued failure to bring down stubbornly high unemployment levels and to produce sufficiently high economic growth to feed Afghanistan's rapidly growing population is likely to have in the near future.

Harrison Akins wraps up this special issue by examining the case of FATA, where the institutional legacy of colonialism continues to shape political interests and conflict within post-colonial societies. He demonstrates that intragroup conflict fostered by these legacies, as well as the ways state political systems interact with these subgroups, helps explain variation in political interests within the community. The internal conflict in FATA also holds broader implications for Pakistani security and regional issues related to Afghanistan. Akins concludes by describing how conflict between highly fragmented political elites threatens to derail recent steps toward political reform in FATA.

The papers of this special issue reflect specific moments in time of Afghanistan's development. That context continues to evolve. Notably, Afghanistan in 2014 entered what was heralded in multiple donor conferences as a "transformation decade." Although our papers generally focus on dynamics prior to 20I4, it is nevertheless worth noting three aspects of this transformation, which are already beginning to have significant impacts on the country's future stability and economic and political outlook.

First, after a decade of rapidly increasing international assistance, aid revenues are now on the decline. ${ }^{2}$ After 200I, official development assistance rose 50 -fold in a little over Io years, yet, in competition with the emergence of new global crises, it is now decreasing at a similar pace. (From around US\$ 0.4

I. Bonn Conference, final communiqué, <https://peacemaker.un.org/sites/peacemaker.un.org/ files/AF_III205_BonnConference.pdf>.

2. Nematullah Bizhan, Aid Paradoxes in Afghanistan: Building and Undermining the State (Abingdon, UK: Routledge, 20I8). 
billion in 200I, ODA rose to a high of just under US\$ 7 billion in 20II; by 2016 it had dropped to around US\$ 4 billion.) The large influx of aid fueled rapid economic growth (now at risk of stalling) and led to significant improvements in almost all social indicators; but it also fed corruption and provided revenues to criminal and insurgent groups.

Second, in 20I4, a military transition took place, in which the US and NATO reduced their troop presence by $90 \%$, announced a formal end to their combat operations in Afghanistan, and handed over security responsibility to the Afghan National Security Forces. But the Afghan forces remain reliant on NATO for training and air support, ${ }^{3}$ and the security situation continues to worsen. ${ }^{4}$

Third, 2014 also witnessed a political transition. The disputed presidential election of 20I4, in which both candidates claimed victory, resulted in the establishment of a National Unity government with Ashraf Ghani as president and his opponent, Abdullah Abdullah, taking on the newly created role of chief executive. While it helped prevent conflict between the supporters of the two candidates, this unstable arrangement has exacerbated the adverse effects of the transition due to fragmentation in governance practices and lack of consensus between the two leaders.

International, national, and local politics will each continue to influence the trajectories of Afghanistan's development. Taken as a whole, the papers of this special issue reflect on the long-term legacies of international intervention and state-building in contemporary development in the region. Although the international intervention in Afghanistan will likely continue for the foreseeable future, this is an opportune time to identify lessons learned from the past I7 years, particularly in how well-intentioned aid and development policies have been upended by national and local politics. This special issue is intended as a contribution to academic and policy debates in this arena, and suggests how local and international actors might avoid similar pitfalls in the future. The likelihood of future political, economic, or military setbacks makes such a stock-taking exercise more important than ever.

3. NATO, "NATO and Afghanistan," October I3, 2016, <http://www.nato.int/cps/en/natohq/ topics_8189.htm>; Brookings, "Afghanistan Index," May 25, 20I7, <https://www.brookings.edu/ afghanistan-index/>.

4. Civilian deaths and injuries from combat have increased every year since 2009, when record keeping began, with the sole exception of 2012. United Nations Assistance Mission in Afghanistan (UNAMA), Afghanistan: Protection of Civilians in Armed Conflict. Annual Report 2016 (Kabul: UNAMA, 20I7). 